\title{
ASAM JAWA(Tamarindus Indica L) DAN INTENSITAS NYERI DISMENOREA PRIMER PADA REMAJA PUTRI
}

\author{
Alfina Aisatus Saadah, Didien Ika Setyarini, Tri Mardiyanti \\ Poltekkes Kemenkes Malang, Jl. Besar Ijen No 77 C Malang \\ Email: jurnal@poltekkes-malang.ac.id
}

\section{The Effect Of Giving Tamarind (Tamarindus Indica L) To The Intensity Of Primary Dysmenorrhoea Pain In Adolescent Girls}

\begin{abstract}
This study aims to determine the effect of giving tamarind (Tamarindus indica L) to the intensity of primary dysmenorrhoea pain in adolescent girls. Pre-experimental research design with onegroup pre test post test design, population of 45 female student and 42 samples, sampling technique used is total sampling. Data collection methods using an observation sheet. The result of data analysis got $Z$ value count bigger than $Z$ table $(5,708>2,576)$, and sig $z$ smaller than $\alpha(0,000<0,01)$ so it can be concluded that $H_{0}$ rejected means there is influence of giving of tamarind (Tamarindus indica L) Intensity of primary dysmenorrhoea pain in adolescent girls.
\end{abstract}

Keywords: tamarind, primary dysmenorrhea, adolescents

\begin{abstract}
Abstrak: Penelitian ini bertujuan untuk mengetahui pengaruh pemberian asam jawa (Tamarindus indica $L)$ terhadap intensitas nyeri dismenorea primer pada remaja putri. Desain penelitian yang digunakan pra eksperimen dengan rancangan onegroup pre test post test, jumlah populasi 45 siswi dan sampel 42 siswi, teknik sampling yang digunakan total sampling, metode pengumpulan data dengan menggunakan lembar observasi. Hasil analisa data didapatkan nilai $Z$ hitung lebih besar dari $Z$ tabel $(5,708>2,576)$, dan sig $z$ lebih kecil daripada á $(0,000<0,01)$ sehingga dapat disimpulkan bahwa $H_{0}$ ditolak artinya ada pengaruh pemberian asam jawa (Tamarindus indica $L$ ) terhadap intensitas nyeri dismenorea primer pada remaja putri.
\end{abstract}

Kata Kunci: asam jawa, dismenorea primer, remaja

\section{PENDAHULUAN}

Menstruasi merupakan perdarahan secara periodik dan siklik dari uterus, disertai pelepasan (deskuamasi) endometrium (Sarwono, 2008). Dalam kondisi normal, menstruasi tidak menyebabkan gangguan yang cukup berarti (Soebachman dan Kissantie, 2006). Hal ini karena menstruasi normal merupakan hasil interaksi antara hipotalamus, hipofisis dan ovarium. Pada individu tertentu, menstruasi dapat menimbulkan nyeri yang disebut dismenorea (Aden, 2010).

Dismenorea merupakan rasa nyeri saat menstruasi yang dapat mengganggu kehidupan sehari-hari wanita (Ayu dkk, 2010). Dismenorea diklasifikasikan menjadi dua yaitu dismenorea primer dan dismenorea sekuder. Dismenorea primer disebut sebagai nyeri haid sejati, intrinsik, esensial atau fungsional, timbul sejak menarke, berhubungan dengan siklus ovulasi, tidak ada kelainan pada alat reproduksi, dan berkaitan dengan proses hormonal menstruasi. Dismenorea primer terjadi pada wanita usia antara 15 sampai 25 tahun, belum pernah melahirkan, kemudian hilang pada usia akhir 20-an atau awal 30-an. Dismenorea primer terjadi sebelum haid dan berangsur hilang setelah darah haid keluar (Nugroho, 2010). Sedangkan dismenorea sekunder terjadi lebih dari 3 hari, terjadi pada wanita usia dewasa (20-30 tahun), pernah melahirkan, semula tidak pernah mengalami nyeri haid, dan terdapat kelainan pada alat reproduksi seperti mioma, polip endometrial, dan endometriosis (Manuaba, 2010). 
Angka kejadian dismenorea di Indonesia sebesar $64,25 \%$ yang terdiri dari $54,89 \%$ dismenorea tipe primer dan $9,36 \%$ dismenorea tipe sekunder (Info Sehat 2010 dalam Hartinah 2016). Di Jawa Timur jumlah remaja putri yang berusia 10-24 tahun adalah sebesar 56.598 jiwa, dan yang mengalami dismenorea sebesar 11.565 jiwa (1,31\%) (BPS Provinsi Jawa Timur 2010 dalam Hartinah 2016).

Ada tiga macam penatalaksanaan untuk mengatasi dismenorea, yaitu terapi farmakologi, nonfarmakologi dan komplementer. Terapi farmakologi terdiri daribahan sintetik seperti obat analgesik. Terapi nonfarmakologi terdiri dari kompres panas pada bagian yang sakit, mandi air hangat, minum-minuman hangat, menggosok/ memijat di daerah perut atau pinggang yang sakit, posisi menungging, dan tarik nafas dalam untuk relaksasi (Nugroho \& Joseph, 2010). Sedangkan terapi komplementer terdiri dari bahan alamiah seperti kunyit, temulawak dan asam jawa digunakan sebagai obat tradisional yang pengujian aktivitas farmakologinya telah dilakukan terhadap hewan percobaan (Afifah, 2004). Asam jawa memiliki aktivitas sebagai antibakteri, anti-peradangan, dan aktivitas antioksidan (Setyawati, 2015).

Asam Jawa (Tamarindus indica L) mempunyai kandungan flavonoid, tannin, alkaloid, anthocyanin, dan asam sitrat yang mempunyai manfaat untuk mengurangi nyeri dismenorea primer (Soedibyo, 1998). Flavonoid memiliki kemampuan sebagai antiinflamasi (Kumoro, 2015). Tannins dan alkaloids memiliki kemampuan sebagai analgesik (Livingstone $e t$ al., 2008). Anthocyanin sebagai antipiretika (Nair et al., 2004). Asam sitrat memiliki kemampuan untuk mengurangi nyeri dismenorea dengan cara menurunkan produksi vasopresin (Suhaimiati \& Handayani, 2006). Asamjawa bisa diberikan ketika seseorang mengalami nyeri haid (dismenorea) dan tidak memiliki efek samping yang berbahaya terhadap sistem tubuh lainnya seperti lambung dan ginjal (Astawan, 2009).

Penelitian yang dilakukan oleh Cahyono dan Wulandari (2010) menyatakan bahwa, ada perubahan intensitas nyeri dismenorea primer sebanyak $60 \%$ yaitu dari 10 responden 6 diantaranya mengalami penurunan intensitas nyeri. Penelitian lain yang dilakukan oleh Amalia (2014) menyatakan bahwa ada perubahan intensitas nyeri dismenorea primer sebanyak $37 \%$ yaitu dari 30 responden 11 diantaranya mengalami penurunan intensitas nyeri.

Studi pendahuluan yang dilakukan peneliti pada bulan November 2016 di SMAAl-Rifa'i Gondanglegi, Kabupaten Malang didapatkan hasil bahwa sekolah tersebut hanya terdiri dari siswi saja, sebagian besar siswi memberi tanda di kalender tanggal menstruasinya dan sering mengalami dismenorea saat haid. Selama ini usaha mereka untuk mengatasi nyeri haid adalah dengan tidur, berposisi menungging, dan memberi kompres hangat pada bagian perut yang sakit. Para siswi belum pernah mengatasi nyeri haid dengan minum asam jawa, meskipun demikian asam jawa tidaklah asing bagi mereka.

Tujuan umum dari penelitian ini adalah untuk mengetahui pengaruh pemberian asam jawa (Tamarindus indica $L$ ) terhadap intensitas nyeri dismenorea primer pada remaja putri kelas XI di SMAAl- Rifa'i Gondanglegi. Tujuan khusus dari penelitian ini adalah mengidentifikasi intensitas nyeri dismenorea primer sebelum pemberian asam jawa (Tamarindus indica $L$ ); mengidentifikasi intensitas nyeri dismenorea primer sesudah pemberian asam jawa (Tamarindus indica $L$ ); menganalisis pengaruh pemberian asam jawa (Tamarindus indica $L$ ) terhadap intensitas nyeri dismenorea primer pada remaja putri.

\section{METODE PENELITIAN}

Desain penelitian ini adalah praeksperimen dengan rancangan onegroup pre test post test. Peneliti mengukur skala nyeri dismenorea dengan 
memberikan lembar observasi yang berisi skala nyeri numerik dan mengamati perilaku remaja putri yang berusia 16-17 tahun dalam menahan nyeri sebelum dan sesudah konsumsi minuman asam jawa.

Populasi dalam penelitian ini adalah seluruh remaja putri kelas XI dengan rentang usia 1617 tahun di SMA Al-Rifa'i Gondanglegi, Kabupaten Malang yang mengalami dismenorea primer sejumlah 42 siswi. Teknik sampling yang digunakan pada penelitian ini adalah Nonprobability sampling dengan teknik total sampling dan didapatkan sampel sebanyak 42 siswi yang memenuhi kriteria inklusi. Terdapat 2 variabel dalam penelitian ini, $v$ ariabel independen yaitu pemberian asam jawa, sedangkan variabel dependennya adalah intensitas nyeri dismenorea primer pada remaja putri.

Kriteria inklusi dalam penelitian ini adalah: tidak sedang mengkonsumsi obat untuk mengurangi nyeri dismenorea primer, tidak menggunakan terapi apapun untuk mengurangi nyeri dismenorea primer, bersedia mengikuti prosedur penelitian, hadir pada waktu penelitian. Kriteria eksklusi dalam penelitian ini adalah: tidak bersedia menjadi responden penelitian.

Alat dan bahan penelitian yang digunakan untuk mengumpulkan data yaitu asam jawa yang telah diolah menjadi minuman asam jawa, timbangan dewasa, microtois, serta lembar observasi yang berisi identitas responden seperti umur, umur menarche, menstruasi hari keberapa, riwayat dismenorea dalam keluarga, tinggi badan dan berat badan.

Penelitian ini dilakukan di SMA Al-Rifa'i Gondanglegi, Kabupaten Malang pada bulan April-Mei 2017.

\section{HASIL PENELITIAN}

Dari hasil penelitian dapat diketahui bahwa sebagian besar $(55 \%)$ responden mengalami menarche pada umur 12-13 tahun. Sebagian besar $(55 \%)$ responden tidak memiliki riwayat dismenorea primer dalam keluarga. Sebagian besar $(71 \%)$ IMT responden dalam kategori normal.

Berdasarkan Tabel 1 dapat dilihat bahwa dari 42 responden terdapat 35 responden yang mengalami penurunan intensitas nyeri, sedangkan 7 responden tidak mengalami penurunan intensitas nyeri. Sebelum pemberian asam jawa responden yang mengalami tidak nyeri berjumlah 0 siswi, sesudah pemberian berjumlah 13 siswi. Sebelum pemberian asam jawa responden yang mengalami nyeri ringan berjumlah 18 siswi, sesudah pemberian berjumlah 23 siswi. Sebelum pemberian asam jawa responden yang mengalami nyeri sedang berjumlah 17 siswi, sesudah pemberian berjumlah 5 siswi. Sebelum pemberian

Tabel 1. Distribusi Frekuensi Responden Berdasarkan Intensitas Nyeri Dismenorea Sebelum dan Sesudah Pemberian Minuman Asam Jawa

\begin{tabular}{lllll}
\hline \multirow{2}{*}{ Intensitas nyeri } & \multicolumn{3}{c}{ Pemberian Asam Jawa } \\
\cline { 2 - 5 } & & Sebelum & \multicolumn{2}{c}{ Sesudah } \\
\cline { 2 - 5 } & F & $\%$ & F & $\%$ \\
\hline Tidak Nyeri & 0 & 0 & 13 & 30 \\
Nyeri Ringan & 18 & 43 & 23 & 55 \\
Nyeri Sedang & 17 & 40 & 5 & 12 \\
Nyeri Berat & 6 & 14 & 1 & 3 \\
Nyeri Sangat Berat & 1 & 3 & 0 & 0 \\
\hline Jumlah & 42 & 100 & 42 & 100 \\
\hline
\end{tabular}


asam jawa responden yang mengalami nyeri berat berjumlah 6 siswi, sesudah pemberian berjumlah 1 siswi. Sebelum pemberian asam jawa responden yang mengalami nyeri sangat berat berjumlah 1 siswi, sesudah pemberian berjumlah 0 siswi.

Berdasarkan hasil uji statistic Wilcoxon Signed Ranks test dengan menggunakan program komputer didapatkan $\mathrm{Z}$ hitung sebesar -5,708 (harga (-) tidak diperhitungkan karena harga mutlak) dan sig z sebesar 0,000. Berdasarkan perhitungan di atas ternyata $Z$ hitung lebih besar daripada $Z$ tabel $(5,708>2,576)$, dan sig z lebih kecil daripada $\alpha(0,000<0,01)$ dengan demikian $\mathrm{H}_{0}$ ditolak. Maka dapat disimpulkan bahwa ada pengaruh pemberian asam jawa (Tamarindus indica $L$ ) terhadap intensitas nyeri dismenorea primer pada remaja putri kelas XI di SMAAl-Rifa'i Gondanglegi.

\section{PEMBAHASAN}

Hasil penelitian dijelaskan bahwa sebagian besar $(55 \%)$ responden mengalami menarche pada umur 12-13 tahun.. Dismenorea primer umumnya terjadi beberapa waktu setelah menarche biasanya kurang dari 12 bulan atau lebih, karena siklus haid pada bulan pertama setelah menarche belum teratur atau berjenis anovulatoar (tidak terjadi pelepasan sel telur) sehingga tidak disertai dengan rasa nyeri (Sarwono, 2008).

Menurut Bare dan Smeltzer (2002), faktor risiko terjadinya dismenorea primer adalah menarche pada usia lebih dini < 11 tahun. Dijelaskan bahwa menarche pada usia lebih awal menyebabkan alat-alat reproduksi belum berfungsi secara optimal dan belum siap mengalami perubahan-perubahan sehingga timbul nyeri ketika menstruasi. Menurut Judha (2012), bahwa faktor risiko yang berhubungan dengan kejadian dismenorea primer adalah menarche pada usia amat dini $<11$ tahun karena jumlah folikel-folikel ovary primer masih dalam jumlah sedikit sehingga produksi estrogen juga sedikit sehingga menimbulkan nyeri dismenorea saat menstruasi.

Berdasarkan hasil dapat disimpulkan bahwa sebagian besar $(55 \%)$ responden tidak memiliki riwayat dismenorea primer dalam keluarga. Menurut Judha (2012), faktor risiko terjadinya dismenorea adalah memiliki riwayat dismenorea primer dalam keluarga karena gejala dismenorea sama dengan endometriosis dimana terjadi nyeri saat menstruasi akibat pengaruh hormon estrogen sehingga bisa dipengaruhi oleh faktor genetik. Wanita dengan ibu, bibi atau saudara perempuan kandung yang menderita endometriosis maka memiliki risiko 7 kali lebih besar terkena penyakit ini juga karena terdapat gen abnormal yang diturunkan dibandingkan dengan orang normal. Wanita yang memiliki riwayat dismenorea dalam keluarga maka akan mengalami dismenorea saat menstruasi, dikarenakan kondisi anatomis dan fisiologis dari seseorang pada umumnya hampir sama dengan orang tua dan saudara-saudaranya (Patruno, 2006).

Hasil penelitian didapatkan sebagian besar (71\%) IMT responden dalam kategori normal. Menurut Judha (2012), bahwa faktor risiko yang berhubungan dengan kejadian dismenorea primer adalah wanita obesitas karena bisa menyebabkan perubahan hormonal dan sistem reproduksi seperti mengakibatkan anovulatory cronic sehingga mempengaruhi pembentukan hormon terutama estrogen yang diakibatkan timbunan lemak yang berlebih. Wanita dengan obesitas dapat menimbulkan dismenore, karena terdapat jaringan lemak yang berlebihan dan mengakibatkan hiperplasi pembuluh darah yaitu terdesaknya pembuluh darah oleh jaringan lemak pada organ reproduksi wanita sehingga darah yang seharusnya mengalir pada proses menstruasi terganggu dan menimbulkan nyeri (Proverawati, 2009).

Berdasarkan hasil penelitian pada Tabel 1 dapat diketahui bahwa dari 42 responden terdapat 35 responden yang mengalami 
penurunan intensitas nyeri, sedangkan 7 responden tidak mengalami penurunan intensitas nyeri. Sebelum pemberian asam jawa responden yang mengalami tidak nyeri berjumlah 0 siswi, sesudah pemberian berjumlah 13 siswi. Sebelum pemberian asam jawa responden yang mengalami nyeri ringan berjumlah 18 siswi, sesudah pemberian berjumlah 23 siswi. Sebelum pemberian asam jawa responden yang mengalami nyeri sedang berjumlah 17 siswi, sesudah pemberian berjumlah 5 siswi. Sebelum pemberian asam jawa responden yang mengalami nyeri berat berjumlah 6 siswi, sesudah pemberian berjumlah 1 siswi.Sebelum pemberian asam jawa responden yang mengalami nyeri sangat berat berjumlah 1 siswi, sesudah pemberian berjumlah 0 siswi. Hal ini menunjukkan bahwa adanya pengaruh pemberian asam jawa (Tamarindus indica $L$ ) terhadap intensitas nyeri dismenorea primer pada remaja putri kelas XI.

Pada uji statistik wilcoxon signed ranks test dengan menggunakan program komputer dengan taraf signifikansi 0,005 dan nilai $\alpha$ pada tingkat kesalahan $1 \%$ adalah 0,01 , didapatkan nilai $\mathrm{Z}$ hitung lebih besar daripada $\mathrm{Z}$ tabel $(5,708>$ 2,576), dan sig $\mathrm{z}$ lebih kecil daripada á $(0,000<0,01)$ dengan demikian terjadi penolakan terhadap H0, sehinngga dapat disimpulkan bahwa ada pengaruh pemberian asam jawa (Tamarindus indica $L$ ) terhadap intensitas nyeri dismenorea primer pada remaja putri kelas XI.

Menurut teori yang dikemukakan oleh Manuaba (2010), sejak saat ovulasi (pengeluaran sel telur) telah terjadi penurunan pengeluaran estrogen dan progesteron. Kepincangan penurunan estrogen/progesteron menimbulkan efek kerusakan jaringan melalui ishemia sehingga enzim lipoksigenase dan sikloksigense dilepaskan, terjadi kerusakan membrane sel sehingga dikeluarkanlah fosfolipid, asam arakidonat, dan ion kalsium. Terjadi pembentukan prostaglandin dan vasopressin sehingga terjadi vasokonstriksi pembuluh darah arteri spiralis, ishemia endometrium bagian atas, merusak jaringan. Kedua senyawa tersebut mengakibatkan kontraksi otot uterus semakin kuat, tekanan intrauterine semakin tinggi, kontraksi otot uterus semakin menjepit ujungujung serat syaraf, rangsangannya dialirkan melalui serat syaraf simpatikus dan parasimpatikus, sehingga terjadi dismenorea primer.

Dismenorea primer bisa disebabkan oleh faktor hormon, faktor psikologi, prostaglandin, vasopresin, sistem saraf, dan faktor konstitusi. Prostaglandin merupakan senyawa yang bisa menyebabkan spasme miometrium yang kuat. Prostaglandin menyebabkan peningkatan aktivitas otot uterus maupun peningkatan kepekaan serabut-serabut terminal rangsang nyeri. Penyerapan prostaglandin ke dalam peredaran darah uterus ketika endometrium terlepas merupakan penyebab terjadinya dismenorea saat menstruasi. Selain prostaglandin, vasopressin juga bisa menyebabkan peningkatan kontraksi otot uterus. Vasopressin memiliki kekuatan lebih besar dalam kontraksi otot uterus daripada hormon hipofisis posterior (oksitoksin). Jadi dapat disimpulkan bahwa penyebab nyeri dismenorea disebabkan oleh terdapatnya abnormalitas dalam distribusi dari jaringan ikat disekitar ostium uteri internum. Nyeri pada dismenorea primer timbul akibat kontraksi uterus disritmik, dilatasi tidak sempurna sfinkter fungsional pada ismus uteri, serta vasokonstriksi pembuluh darah uterus dengan akibat timbulnya nyeri iskemik (Baziad, 2003).

Berdasarkan teori yang ada, dijelaskan bahwa asam jawa bisa mengatasi nyeri dismenorea primer karenamampu menghambat produksi vasopresin dan sintesa prostaglandin dengan memblokir siklooksigenase (COX), dan menghambat leukotrien dengan memblokir lipooksigenase yang merupakkan mediator inflamasi. Selain itu, asam jawa juga menghambat metabolisme asam arakidonat dengan cara melalui jalur siklooksigenase dan lipoksigenase. 
Jalur lipoksigenase merupakan jalur yang penting untuk membentuk bahan-bahan proinflamasi yang kuat. 5-lipoksigenase merupakan enzim metabolit asam arakidonat utama pada neutrofil. Produk dari aksinya memiliki karakteristik yang terbaik. 5-HPETE (asam 5-hidro peroksi eikosa tetranoik) merupakan derivat 5-hidroperoksi asam arakidonat yang tidak stabil dan direduksi menjadi 5-HETE (asam 5-hidroksi eikosa tetraenoik) (sebagai kemotaksis untuk neutrofil) atau diubah menjadi golongan senyawa yang disebut leukotrien. Produk dari 5-HPETE adalah leukotrien (LT) A4 (LTA4), LTB4, LTC4, LTD4, dan LTE4. LTC4, LTD4, dan LTE4 merupakan agen yang bisa menyebabkan vasokonstriksi pembuluh darah (Kumoro, 2015).

Asam jawa dapat merangsang produksi progesteron yang dihasilkan oleh jaringan ikat kelenjar indung telur (corpus luteum) setelah melepaskan sel telur matang setiap bulan dalam jumlah yang stabil. Kestabilan hormon progesteron akan memperkecil ketegangan mulut rahim karena akan menghambat sintesis prostaglandin saat degenerasi endometrium dan pengeluaran pertama darah haid sehingga dapat membantu meredakan kontraksi yang terjadi pada otot rahim (miometrium). Selain itu, kadar progesteron yang cukup akan memperlancar peluruhan endometrium (Suharmiati, 2005). Kandungan senyawa kimia alami yang terdapat didalam daging buah asam jawa efektif dalam mengurangi nyeri dismenorea primer, dimana dari hasil penelitian terjadi penurunan intensitas nyeri dismenorea primer setelah dilakukan observasi selama 1 jam dari sebelum dan sesudah mengonsumsi asam jawa.

Penelitian yang dilakukan oleh Cahyono dan Wulandari (2010) membuktikan bahwa asam jawa bermanfaat dalam mengurangi nyeri dismenorea primer. Dalam penelitiannya disebutkan bahwa ada perubahan intensitas nyeri dismenorea primer sebanyak $60 \%$ yaitu dari 10 responden 6 diantaranya mengalami penurunan intensitas nyeri.

Hal ini sesuai teori yang dikemukakan oleh Azwar (2010), yang menyebutkan bahwa didalam kandungan asam jawa terutama pada bagian daging buah bisa membantu mengurangi nyeri haid dengan memperlancar peluruhan endometrium saat haid, membantu memperlancar peredaran darah ke uterus, dan mencegah peningkatan kontraksi uterus.

Faktor risiko terjadinya dismenorea primer tidak hanya karena umur menarche yang terlalu dini, wanita yang memiliki riwayat dismenorea dikeluarga, dan obesitas. Tetapi terdapat faktor lain seperti keletihan akibat aktivitas yang terlalu padat karena kegiatan di SMAAl-Rifa'i tidak hanya pembelajaran umum di sekolah tetapi juga terdapat pembelajaran ilmu agama di pondok dan adanya kegiatan ekstrakulikuler, faktor psikologi akibat terlalu banyak materi pembelajaran yang harus dipelajari, lama tidak bertemu dengan orangtua sehingga menimbulkan rasa cemas yang akan mempengaruhi hubungan syaraf pusat khususnya talamus dan korteks, dan rasa takut apabila mengikutipenelitian akan dikenakan biaya, selain itu persepsi terhadap nyeri setiap individu berbeda karena berasal dari daerah, budaya dan pola asuh keluarga yang berbeda pula.

\section{PENUTUP}

Berdasarkan hasil penelitian yang telah dilakukan di SMA Al-Rifa'i Gondanglegi, Kabupaten Malang dapat disimpulkan bahwa sebelum diberikan minuman asam jawa dengan jumlah responden 42 siswi, didapatkan jumlah responden yang mengalami tidak nyeri ada 0 siswi, responden yang mengalami nyeri ringan ada 18 siswi, responden yang mengalami nyeri sedang ada 17 siswi, responden yang mengalami nyeri berat ada 6 siswi, dan responden yang mengalami nyeri sangat berat ada 1 siswi. Sesudah diberikan minuman asam jawa didapatkan jumlah responden yang mengalami 
tidak nyeri ada 13 siswi, responden yang mengalami nyeri ringan ada 23 siswi, responden yang mengalami nyeri sedang ada 5 siswi, responden yang mengalami nyeri berat ada 1 siswi, dan responden yang mengalami nyeri sangat berat ada 0 siswi. Pada uji statistik wilcoxon signed ranks test dengan menggunakan program komputer, didapatkan nilai $Z$ hitung lebih besar daripada $\mathrm{Z}$ tabel (5,708 > 2,576), dan sig z lebih kecil daripada á $(0,000<$ 0,01). Dengan demikian terhadap $\mathrm{H}_{0}$ ditolak. Maka dapat disimpulkan bahwa ada pengaruh pemberian asam jawa (Tamarindus indica $L$ ) terhadap intensitas nyeri dismenorea primer pada remaja putri kelas XI.

Tenaga kesehatan terutama bidan dapat menjadikan hasil penelitian ini sebagai informasi tambahan dalam memberikan asuhan gangguan kesehatan reproduksi remaja, yaitu sebagai alternatif manajemen nyeri dismenorea primer secara komplementer.

\section{DAFTAR PUSTAKA}

Aden. 2010. Ketika Remaja dan Pubertas Tiba. Yogyakarta: Hanggar Kreatif.

Amalia dan Sulistyowati. (2014). Pengaruh Jahe Asam terhadap Pengurangan Nyeri Dismenorea pada Siswi Kelas XI SMA N 1 Sukodadi. Stikes Muhamadiyah Lamongan. Hlm 235-241.

Astawan, M.(2009). Sehat Dengan Hidangan Kacang Dan Biji-Bijian. Bogor: Penebar Swadaya.

Ayu dkk. 2010. Buku Ajar Ginekologi Untuk Mahasiswa Kebidanan. Jakarta :EGC. Cahyono dan Wulandari. (2010). Pengaruh Pemberian Kunyit Asam terhadap Dismenorea pada Siswi SMP N 2 Grogol. Fakultas Keperawatan Pamenang Kediri. Halm 28-33.
Judha, M. (2012). Teori Pengukuran Nyeri dan Nyeri Persalinan. Yogyakarta : Nuha Medika.

Kumoro, A. (2015). Teknologi Ekstraksi Senyawa Bahan Aktif dari Tanaman Obat. Yogyakarta: Plantaxia.

Livingston R.N.R., Jegan N., \& Wesley J. (2008).Antiulcerogenic activity of alcoholic extract of the leaves of Tamarindus indica (L) on experimental ulcer models. Pharmacol Online.

Manuaba. (2010). Buku Ajar Penuntun Kuliah Ginekologi. Jakarta : CV Trans Info Media.

Manuaba. (2010). Kapita Selekta Penatalaksanaan rutin Obstetri Ginekologi dan $K B$. Jakarta : EGC.

Nugroho dan Joseph. (2010). Catatan Kuliah Ginekologi dan Obstetri. Yogyakarta : Nuha Medika.

Proverawati dan Asfuah. (2009). Gizi untuk Kebidanan. Yogyakarta: Nuha Medika

Sarwono. (2008). Ilmu Kandungan Edisi Ketiga Cetakan Kedua. Jakarta: Yayasan Bina Pustaka.

Setyawati, Nur. (2015). Dasar-Dasar Farmakologi Keperawatan. Yogyakarta : Binafsi Publisher.

Soebachman S. dan Kissantie S.R. (2006). Rahasia Pintar Kesehatan Wanita. Yogyakarta : In Azna Books.

Soedibyo,M. (1998). Alam Sumber Kesehatan Manfaat Dan Kegunaan. Jakarta : Balai Pustaka.

Suharmiati \& Handayani, L. (2006). Cara benar meracik obat tradisional. Jakarta: Agromedia Pustaka. 